\title{
Spring diet and feeding strategy of the European sprat Sprattus sprattus (L., 1758) from the Black Sea coast of Turkey
}

\author{
Bahar Bayhan", Tuncay Murat Sever \\ Ege University, Faculty of Fisheries, 35040Bornova/Izmir, Turkey
}

\section{A R T I C L E I N F O}

\section{Article history:}

Received 04 May 2015

Accepted 08 July 2015

Available online, ISSN: 2148-127X

Keywords:

European sprat

Sprattus sprattus

Diet composition

Feeding strategy

Zooplankton

Corresponding Author:

E-mail: bahar.bayhan@ege.edu.tr

\begin{abstract}
A B S T R A C T
This study aims to identify the spring diet composition and feeding strategy of the European sprat, Sprattus sprattus. Diet composition of European sprat was investigated for the first time in the central Black Sea coast of Turkey. Examined of the 115 specimens (6 - $9.1 \mathrm{~cm}$ total length) of stomach, $12(10.4 \%)$ had emty. Diet analysis was described based on gravimetric percentages (W\%), frequency of abundance (N\%), frequency of occurrence $(\% \mathrm{~F})$ and relative importance index (IRI\%). Feeding strategy was analyzed and graphically (Costello) represented, considering the frequency of abundance $(\mathrm{N} \%)$ and frequency of occurrence $(\% \mathrm{~F})$ indexes and grouping prey into higher taxonomic categories. Twenty species were identified, belonging to four prey groups: Polychaeta, Crustacea, Mollusca and Chaetognatha. Finally copepods proved to be the most important food item considering the above-cited indexes. All other prey taxa were identified as accidental preys. At least seven copepod species were identified, where Calanus euxinus appeared all round with $\% \mathrm{IRI} \geq 50$. Also results of feeding strategy analyses revealed a trophic specialization toward a single prey.
\end{abstract}

Türk Tarım - Gıda Bilim ve Teknoloji Dergisi, 3(9): 697-700, 2015

Türkiye'nin Karadeniz kıyılarındaki Çaça balığı Sprattus sprattus (L., 1758)'nın ilkbahar diyeti ve beslenme stratejisi

M A K A L E B İ L G İ S İ

Geliş 04 Mayıs 2015

Kabul 08 Temmuz 2015

Çevrimiçi baskı, ISSN: 2148-127X

Anahtar Kelimeler:

Çaça balığ 1

Sprattus sprattus

Diyet kompozisyonu

Beslenme stratejisi

Zooplankton,

\footnotetext{
Sorumlu Yazar:

E-mail: bahar.bayhan@ege.edu.tr
}

\section{Ö Z E T}

Bu çalıșmanın amacı; Çaça balığı Sprattus sprattus'un ilkbahar mevsimindeki diyet kompozisyonu ve beslenme stratejisini belirlemektir. Çaça balığının diyet kompozisyonu Türkiye'nin Karadeniz kıyılarında ilk defa incelenmiştir. 115 bireyin (6-9,1 $\mathrm{cm}$ total boy) midesi örneklenmiştir, 12 adedi $(\% 10,4)$ boş olarak saptanmıştır. Diyet analizleri; gravimetrik yüzde $(\% \mathrm{~W})$, bolluk frekansı $(\% \mathrm{~N})$, bulunuş frekansı $(\% \mathrm{~F})$ ve nispi önemlilik indeksi (\%IRI) temel alınarak tanımlanmıştır. Beslenme stratejisi analiz edilmiştir ve grafik olarak (Costello) gösterilmiştir, bolluk frekansı $(\% \mathrm{~N})$ ve bulunma frekans $(\% \mathrm{~F})$ indeksleri dikkate alınmışıır ve sistematik kategorilere göre avlar gruplanmıştır. Polychaeta, Crustacea, Mollusca ve Chaetognatha olmak üzere 4 av grubuna ait 20 tür belirlenmiştir. Sonuç olarak Kopepodlar yukarıda bahsedilen tüm indeksler dikkate alındığında en önemli besin olarak saptanmıştır. Diğer tüm av grupları rastgele avlar olarak belirlenmiştir. Calanus euxinus türünün $\% \mathrm{IRI} \geq 50$ değerinde saptandığ kopepod türü belirlenmiştir. Ayrıca beslenme stratejisi analizine göre tür, tek bir av grubuna doğru trofik uzmanlaşma göstermektedir. 


\section{Introduction}

The European sprat Sprattus sprattus (Linnaeus, 1758) is a small pelagic and schooling clupeid fish, distributed in shelf waters of the Northeast Atlantic, including the Mediterranean, Black Sea, North Sea and Baltic Sea (Limborg et al., 2009). The Baltic Sea is a suitable area for the reproductive potential of the species. Although the Baltic Sea has been exposed to a lot of ecological changes over the last twenty years, the sprat population has been reported to increase in a dramatic way (Ivanov and Beverton, 1985).

The Black Sea is one of the most isolated seas in the world. The Black Sea coast of Turkey is the most fertile sea with approximately $71 \%$ of the annual fish production. The production amount of sprat on Turkish coasts is 9764 tones, 9758,6 tones coming from the Black Sea and only 5,4 tones obtained from the Marmara Sea (TÜIK, 2013). Also, the Sprat production takes the fifth place in total fish production following Anchovy, Horse Mackerel, Sardine, and Bonito. Sprat show a wide distribution in the European coast of the Mediterranean, especially in the Adriatic and Black Sea, and its economic value has significantly increased over the last couple of years (Avşar, 1994). Sprat fishing was only done with traps and net fishing in all countries that it is found until 1970. After 1970, pelagic trawls were introduced in Bulgaria (Ivanov and Beverton, 1985). The first commercial sprat fishing in Turkey was performed in the early 1990's with midwater trawls in the central Black Sea. The species does not have a direct consumption habit in Turkey, almost all of the produced amount is used as raw material in fishmeal and fish oil factories. Not having a consumption habit, use of sprat as the raw material needed in fishmeal and fish oil factories instead of anchovy is reported to be both more economical and also a great asset to national fishing, since it means making use of an underutilized resource found in our seas (Kalayc1 et al., 2006). Furthermore small pelagic fish comprise important ecological links between plankton production and higher, piscivorous trophic levels; these fish are of substantial economic importance. The species has an important role in the food chain in regions it is found as it takes part in diet composition of its predators such as Merlangius merlangus (Hislop et al., 1991) and Merluccius merluccius (Du Buit, 1996). Sprat is an ecologically important pelagic fish species, acting as a link between plankton and production on higher trophic levels. Data on feeding habits in aquatic ecosystems are of great importance in determining the role that a certain fish species plays in its habitat and in related ecosystems. The availability of suitable food is usually considered to be a key factor in determining the recruitment and growth of fish. Nowadays, trophic levels are used in order to develop ecosystem based fisheries management strategies. Depending on the trophic controls forming upwards from the lowest level and downwards from the highest level of the food chain, long-term changes in fish stocks and leaps between low and high stock regimes can be identified (Daskalov, 2002). Although there are a large number of articles related to the feeding ecology of sprat in the Baltic (Arrhenius, 1996; Möllmann et al., 2004; Casini et al., 2004; Baumann et al., 2007) and the North Sea (Last,
1987; Voss et al., 2009; Falkenhaug and Dalpadado, 2014). Unfortunately, the number of studies on the biological properties of this species found in Turkish coast is limeted (Avşar, 1994; Şahin, 1999) and there is not any study available on its diet composition.

In our study conducted as a pioneer in this sense, the diet composition and strategy of sprat, found in the Black Sea coast of Turkey, will be identified for the first time. The resulting findings will undoubtedly be a reference for more detailed future studies on the diet composition and habits of the species. Also, in line with ecosystem-based fisheries management widely used today, we hope that this study will contribute to development of management strategies of this species, which has economic value for the Black Sea coast of Turkey.

\section{Material and Methods}

Samples were obtained from commercial fishermen, who generally use two boat pelagic trawl in Black Sea coast of Turkey (coordinates between $41^{\circ} 41,040^{\prime} \mathrm{N}-35^{\circ}$ 25,193' $\mathrm{E}$ and $41^{\circ} 08,874^{\prime} \mathrm{N}-37^{\circ} 10,112^{\prime} \mathrm{E}$ ), which consist of sprat fishing grounds in central part of the Black Sea concerned during spring 2014.

A total of $115 \mathrm{~S}$. sprattus were collected all year round, with total lengths ranging 6.0 to $9.1 \mathrm{~cm}(65$ in $6-$ $7.5 \mathrm{~cm} ; 50$ in $>7.5 \mathrm{~cm})$. Fish stored in formalin $(10 \%)$ until the they were analysed. Stomach contents were homogenized in petri dishes, which were then, examined using a SZX7 Olympus stereo microscope at 0.8-5.6x (zoom) and 10x resolution. Prey items were identified to the lowest possible taxon, except for Copepoda, where identification was made at the species or generic level. In case of digested copepods, identification was made from body parts (MPC, 2015).

Once counted, the individuals of the same species were weighed together (wet weight to the nearest \pm 0.0001 $\mathrm{g}$ ), after excess moisture was removed by blotting prey items on tissue paper. Following indices have been used to quantify the importance of different prey items in the diets of S. sprattus:

- $\quad$ Percentage frequency of occurrence $(\mathrm{F} \%)$ for each prey groups computed separetly $=$ the number of stomachs in which a food item was found divided by the total number of non-empty stomachs, multipled by 100 .

- Percentage numerical abundance $(\mathrm{N} \%)=$ the number of each prey item in all non-empty stomachs, divided by the total number of food items in all stomachs, multipled by 100 .

- $\quad$ Percentage gravimetric composition $(\mathrm{W} \%)=$ the wet weight of each prey item, divided by the total weight of stomach contents, multiplied by 100 (Hyslop, 1980).

The main food items were identified using the index of relative importance IRI $=\mathrm{F} \% *(\mathrm{~N} \%+\mathrm{W} \%)$. The index was expressed as: IRI $\%=\left(\right.$ IRI $/ \sum$ IRI $) * 100$.

The percentage of empty stomachs to the total number of examined stomachs was expressed as the vacuity index 
(VI). Vacuity index, VI\% = $100 \mathrm{x}$ (number of empty stomachs / number of examined stomachs) (Berg, 1979). Costello defined relative abundance of prey as the percentage of total stomach contents (volume, weight or numbers) in all predators comprised by that given prey. Differences in the diet composition of the sprat were analysed using the graphical method (Costello, 1990) (Fig. 1).

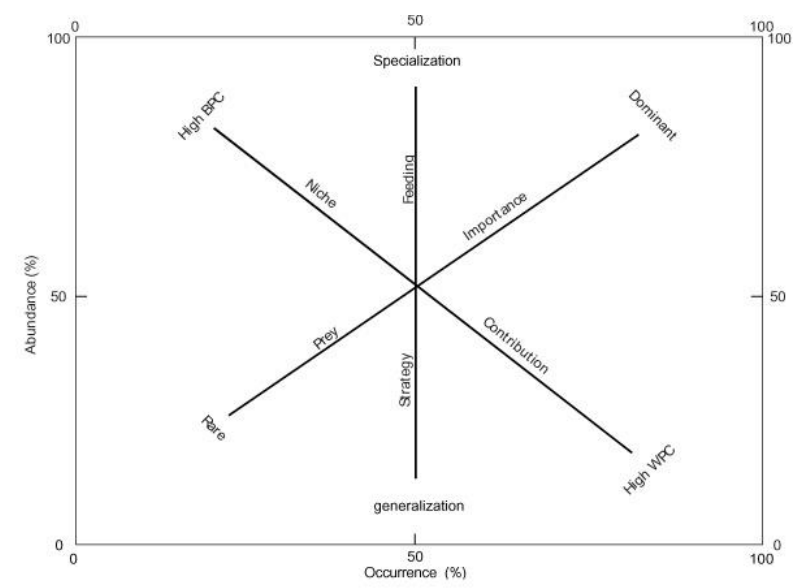

Fig. 1 Costello graphic

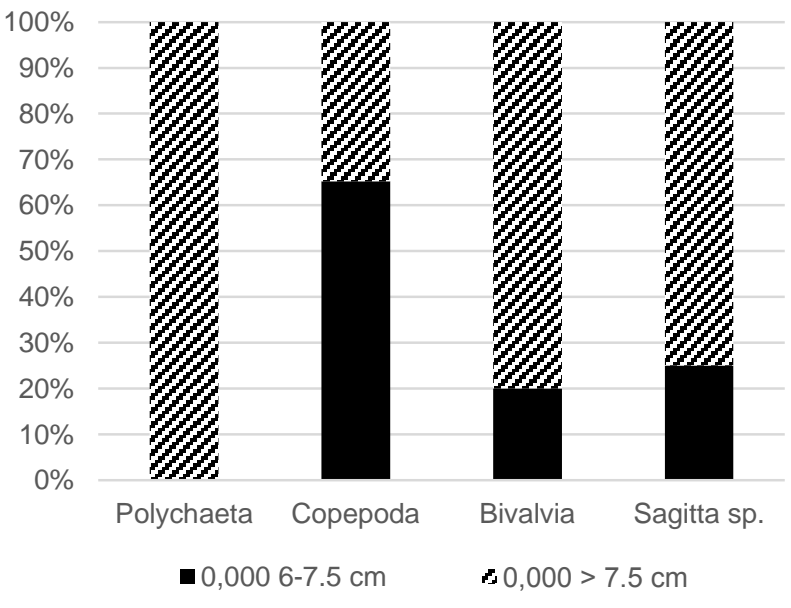

Fig 2 Percentage numerical abundance (N\%) of main food groups in Sprattus sprattus' diet by size groups

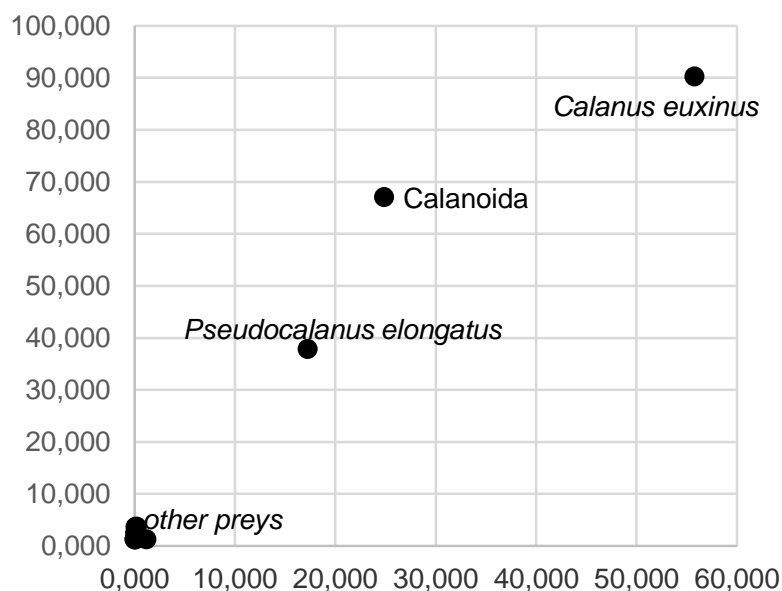

Fig 3 Relationship between prey-specific abundance and frequency of occurrence of prey items in the diet of Sprattus sprattus, collected in the Turkish Black Sea coast

\section{Results and Discussion}

Examined of the 115 specimens of stomach, 12 were found to be emty. The vacuity index was low during spring (10.4\%). The percentages of empty stomachs closer to ours were observed in the Hardangerfjord, western Norway $(10.1 \%$, 5.6\% for 2009 and 2010 spring period respectively) (Falkenhauga and Dalpadado, 2014).

Stomach contents of a total of individuals were examined in the study, and it was identified that the species fed on Copepoda (especially calanoida, Calanus euxinus and Pseudocalanus elongatus) in terms of quantitative presence and relative importance index (Table 1). The Black Sea zooplankton community structure is more productive. Generally most of researches were made about copepod species. Eight copepods species (e.g. C. euxinus, A. clausi, P. elongatus e.g) were identified in the Sinop region (Bat et al., 2011). In addition, there is not much data on zooplankton species composition of the central Black Sea region, since most studies conducted in the Black Sea focused on the coastal part. However, many species available in coastal waters are known to be available in the central Black Sea, e.g. Sagitta setosa or copepods such as $C$. exinus and $P$. elongatus (Kovalev et al., 1999; Deniz and Gönülol, 2014). Therefore, we see that copecod species found in stomach contents of sprat are consistent with copecod species previously identified in the environment.

According to several studies on the diet composition of the species, sprat is planktivore and feeds particularly on planktonic copepods, which is similar to our findings (Sirotenko and Sorokalit, 1979; Last, 1987; Thiel et al., 1996; Oven et al., 1997). For example, copepods were found to be among the most important prey of sprat in Hardangerfjord. The numerically most important food species for sprat in the Hardangerfjord was the planktonic harpacticoid copepod Microsetella norvegica (Falkenhaug and Dalpadado, 2014). This is in agreement with previous studies on sprat from the North Sea (De Silva, 1973; Last, 1987; Voss et al., 2009) and the Baltic Sea (Arrhenius, 1996; Möllmann et al., 2004; Casini et al., 2004). Also another study have shown a high selectivity for Temora, which is related to its high swimming activity (Möllmann et al., 2004) and Centropages hamatus (Baumann et al., 2003). Therefore, it can be said that sprat's diet composition varies depending on zooplankton species composition of different habitats, in other words, sprat's preferred feeding group consists of prey group found abundantly in the environment.

The diet composition of the species varies slightly depending on the length. For example, polychaetes were observed only in the fish group longer than $7.5 \mathrm{~cm}$ in terms of qualitative abundance, while the other food group consisting of copepod, bivalvia and sagitta was observed in both length groups (Fig. 2). Similarly, with increasing size of sprat larvae, a trend towards larger prey items was observed. For example, Clausocalanoid nauplii were by far the most important prey item for small sprat larvae $(3.5-<8.5 \mathrm{~mm})$ followed by the group of unidentified copepods. In the $8.5-<14.5 \mathrm{~mm}$ length class clausocalanoid nauplii were the most frequently occurring prey, while unidentified copepods dominated by weight in the German Bight, North Sea (Voss et al., 2009). 
According to Costello graph analysis, it was determined that $C$. exuinus from copepods, dominant calanodia and $P$. elongatus were important in the feeding strategy of sprat during spring, and other prey groups identified in the stomach content of the species had low importance (Fig. 3).

In conclusion, this study is the first attempt to provide detailed information on the diet composition and feeding strategy of sprat in the Black Sea coast of Turkey. We have shown that sprat feeds on small-sized prey.

Table 1 Principal prey items found in diet of sprat Sprattus sprattus (N\%, F\%, W\% and \% IRI, percentage numerical composition, frequency of occurrence, gravimetric composition and of relative importance respectively)

\begin{tabular}{l|rrrr}
\hline \multicolumn{1}{c|}{ Prey groups } & \multicolumn{1}{c}{$\mathrm{N} \%$} & \multicolumn{1}{c}{$\mathrm{F} \%$} & \multicolumn{1}{c}{ W\% } & \multicolumn{1}{c}{ IRI\% } \\
\hline Polychaeta & 0.041 & 1.220 & 0.024 & $\leq 0.001$ \\
Crustacea & & & & \\
Copepoda & & & & \\
$\quad$ Calanoida & 24.887 & 67.073 & 25.212 & 16.801 \\
Acartia clausi & 1.197 & 1.220 & 1.231 & 0.015 \\
Calanus euxinus & 55.799 & 90.244 & 55.684 & 50.303 \\
$\quad$ Paracalanus parvus & 0.041 & 1.220 & 0.041 & 0.001 \\
Pseudocalanus elongatus & 17.251 & 37.805 & 17.216 & 6.515 \\
$\quad$ Oithona spp. & 0.165 & 2.439 & 0.162 & 0.004 \\
$\quad$ Harpacticoida & 0.083 & 2.439 & 0.086 & 0.002 \\
Decapoda & 0.041 & 1.220 & 0.107 & 0.001 \\
Crustacea yumurtas1 & 0.124 & 3.659 & 0.041 & 0.003 \\
Mollusca & & & & \\
Bivalvia & 0.248 & 3.659 & 0.142 & 0.007 \\
Chaetognatha & & & & \\
Sagitta sp. & 0.124 & 1.220 & 0.054 & 0.001 \\
\hline \multicolumn{2}{l}{}
\end{tabular}

\section{Acknowledgements}

We would like to thank K. Özçelik for obtaining the fish samples.

\section{References}

Arrhenius F. 1996. Diet composition and food selectivity of Ogroup herring (Clupea harengus L.) and sprat (Sprattus sprattus (L.) in the northern Baltic Sea. ICES Journal of Marine Science, 53: 701-12.

Avşar D. 1994. Population parameters of sprat (Sprattus spratus phalericus RISSO) from the Turkish Black Sea coast, Fisheries Research, 21: 437- 453.

Baumann H, Peck MA, Götze HE, Temming A. 2007: Starving early juvenile sprat Sprattus sprattus (L.) in western Baltic coastal waters: evidence from combined field and laboratory observations in August and September 2003. Journal of Fish Biology (2007), 70: 853-866.

Bat L, Sezgin M, Satilmis HH, Sahin Üstün F, Özdemir ZB, Baki OG. 2011. Biological Diversity of the Turkish Black Sea Coast. Turkish Journal of Fisheries and Aquatic Sciences, 11: 683-692.

Berg J. 1979. Discussion of methods of investigating the food of fishes, with reference to a preliminary study of the food of Gobiusculus flavescens (Gobiidae). - Marine Biology, 50: 263-273.

Casini M, Cardinale M, Arrhenius F. 2004. Feeding preferences of herring (Clupea harengus) and sprat (Sprattus sprattus) in the southern Baltic Sea. ICES Journal of Marine Science,
61: 1267-77.

Costello MJ. 1990. Predator feeding strategy and prey importance: a new graphical analysis. Journal of Fish Biology, 36: 261-263.

Daskalov GM. 2002. Overfishing drives a trophic cascade in the Black Sea. - Marine Ecology Progress Series, 225: 53-63.

Deniz E, Gönülol A. 2014. Temporal changes of copepod abundance and species compositions in the coastal water of Samsun, the southern Black Sea (Turkey). J. Black Sea/Mediterranean Environment, 20 (3): 164-183

Du Buit MH. 1996. Diet of hake (Merluccius merluccius) in the Celtic Sea. Fisheries Research, 28(4): 381-394.

Falkenhaug T, Dalpadado P. 2014 Diet composition and food selectivity of sprat (Sprattus sprattus) in Hardangerfjord, Norway. Marine Biology Research, 10(3): 203-215.

Hislop JRG, Robb AP, Bell MA, Armstrong DW. 1991. The diet and food consumption of whiting (Merlangius merlangus) in the North Sea. ICES Journal of Marine Science, 48: 139-156.

Hyslop EJ. 1980. Stomach contents analysis - a review of methods and their application.- Journal of Fish Biology 17: 411-429.

Ivanov L, Beverton RJH. 1985. The fisheries resources of the Mediterranean. Part two: Black Sea. Etud. Rev. CGPM/Stud. Rev. GFCM., (60): 135 pp.

Kalayc1 F, Bilgin S, Samsun O, Samsun N. 2006. Researching the place of fisheries industry and general state of the sprat (Sprattus sprattus Phalericus Risso, 1826) fishing Middle Black Sea Region. E.U. Journal of Fisheries \& Aquatic Sciences, 23 (1/3): 449-455.

Kovalev AV, Skryabin VA, Zagorodnyaya Yu A, Bingel F, Kideys AE, Niermann U, Uysal Z. 1999. The Black Sea Zooplankton: Composition, Spatial/Temporal Distribution and History of Investigations. Tr. Journal of Zoology, 23: 195-209.

Last JM. 1987. The food of immature sprat [Sprattus sprattus (L.)] and herring (Clupea harengus) in coastal waters of the North Sea. J. Cons. Int. Explor. Mer. 44: 73-79.

Limborg MT, Pedersen JS, Hemmer-Hansen J, Tomkiewicz J, Bekkevold D. 2009. Genetic population structure of European sprat Sprattus sprattus: Differentiation across a steep environmental gradient in a small pelagic fish. Marine Ecology Progress, Series 379: 213-24.

Möllmann C, Kornilovs G, Fetter M, Koster FW. 2004. Feeding ecology of central Baltic Sea herring and sprat. Journal of Fish Biology, 65: 1563-81.

MPC. 2015. Marine Planktonic Copepods. http://copepodes.obsbanyuls.fr/en/index.php. [Accessed: 03.09.2015].

Oven LS, Shevchenko NF, Giragosov VE. 1997. Size-age composition, feeding, and reproduction of Sprattus sprattus phalericus (Clupeidae) in different sites of the Black Sea. Journal of Ichthyology, 37(9): 769-778.

Sirotenko MD, Sorokalit LK. 1979: Seasonal changes in the food of the Mediterranean sprat, Sprattus sprattus phalericus. Journal of Ichthyology, 19(5): 37-51.

Şahin T. 1999. Some Biological Characteristics of Sprat (Sprattus sprattus phalericus RISSO, 1826) on the Eastern Black Sea Coast. Turkey Journal of Zooloji, 23(1): 249-255, TÜBİTAK, Ankara.

Thiel R, Mehner T, Köpcke B, Kafemann R. 1996. Diet niche relationship among early life stages of fish in German estuaries. Marine Freshwater Research, 47: 123-136.

TÜIK. 2013. Fishery Statistics. Turkish Statistical Institute. Publication Number 4349, ISSN 1013-6177. Ankara, 61 pp.

Voss R, Dickmann M, Schmidt JO. 2009. Feeding ecology of sprat (Sprattus sprattus L.) and sardine (Sardina pilchardus W.) larvae in the German Bight, North Sea. Oceanologia, 51: $117-38$. 